Supporting Information for

\title{
Versatile Target-Guided Screen for Discovering Bidirectional Transcription Inhibitors of a Trinucleotide Repeat Disease
}

Lauren D. Hagler, Sarah B. Krueger, Long M. Luu, Amie N. Lanzendorf, Niya L. Mitchell, J. Ignacio Vergara, L. Daniel Curet, and Steven C. Zimmerman*

*Email: sczimmer@illinois.edu

Department of Chemistry, University of Illinois at Urbana-Champaign, 600 South Mathews Avenue, Urbana, Illinois 61801, United States. 


\section{Table of Contents}

Synthetic Procedures............................................................................ S3

Template-click reactions using $\mathrm{d}(\mathrm{CTG})_{16}, 24$-mer DNA, and buffer....................S11

Monitoring d(CTG $)_{16}$-templated click reactions by HPLC...............................S11

Additional HPLC traces and MS spectra for pairwise click reactions..................S12

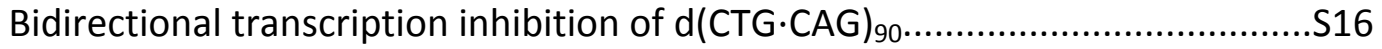

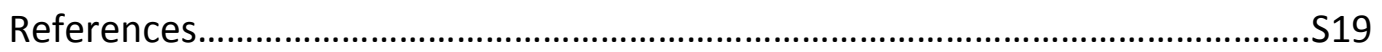




\section{Synthetic procedures}

All non-aqueous reactions were carried out under a dry $\mathrm{N}_{2}$ atmosphere with oven-dried (115 $\left.{ }^{\circ} \mathrm{C}\right)$ glassware. All solvents and reagents were of reagent quality, purchased commercially, and used without further purification unless otherwise indicated. Reactions were monitored by thinlayer chromatography using EMD pre-coated silica gel $60 \mathrm{~F}_{254}$ plates. Flash chromatography was carried out using Silicycle Silica Flash P60 (230-400 mesh) silica gel.

Unless otherwise noted, ${ }^{1} \mathrm{H}$ and ${ }^{13} \mathrm{C}$ NMR spectra were recorded on a $500 \mathrm{MHz}$ Varian Unity Inova spectrometer or a $600 \mathrm{MHz}$ Bruker NEO spectrometer in the NMR lab at the University of Illinois at Urbana-Champaign. All NMR measurements were carried out in DMSO- $d_{6}, C D C_{3}, D_{2} \mathrm{O}$, or $\mathrm{CD}_{3} \mathrm{OD}$ at ambient temperature unless otherwise noted. Chemical shifts are in parts per million $(\mathrm{ppm})$, relative to the residual peaks of DMSO- $d_{6}\left({ }^{1} \mathrm{H}: 2.50,{ }^{13} \mathrm{C}: 39.52\right), \mathrm{CdCl}_{3}\left({ }^{1} \mathrm{H}: 7.26,{ }^{13} \mathrm{C}: 77.06\right)$, $d_{2} \mathrm{O}\left({ }^{1} \mathrm{H}: 4.79\right)$, or $\mathrm{Cd}_{3} \mathrm{Od}\left({ }^{1} \mathrm{H}: 3.31,{ }^{13} \mathrm{C}: 49.03\right)$. Coupling constants $(J)$ are reported in Hertz. Lowresolution electrospray ionization mass spectra (LR-ESI-MS) and MALDI-TOF mass spectra (DHB matrix) were obtained in the Mass Spectrometry Laboratory, School of Chemical Sciences, University of Illinois at Urbana-Champaign.

To determine key compound purity, analytical high performance liquid chromatography (HPLC) was performed using a Shimadzu Prominence system with a UV detector set at $254 \mathrm{~nm}$ and a Shimadzu C18 column (particle size $3 \mu \mathrm{m}$, diameter $4.6 \mathrm{~mm}$, length $5 \mathrm{~cm}$, flow rate 1,500 $\mu \mathrm{L} / \mathrm{min}$ ) with a dual solvent system of $0.1 \%$ TFA in $\mathrm{H}_{2} \mathrm{O}$ (solvent $\mathrm{A}$ ) and $0.1 \%$ TFA in MeCN (solvent B) and an isocratic gradient from $0-100 \% \mathrm{MeCN}$ over $15 \mathrm{~min}$. Preparative HPLC was performed on Agilent Technologies 1260 Infinity II, C-18 $250 \times 50.0 \mathrm{~mm}$ column with a dual solvent system of $0.1 \%$ TFA in $\mathrm{H}_{2} \mathrm{O}$ and $0.1 \%$ TFA in MeCN.

Propiolic acid, diaminobutane, 5-azido-pentylamine, 4-azido-butylamine, 5-azido-pentanoic acid are available from Sigma-Aldrich or can be easily prepared using known procedures.

Compounds 2, 3, 4, 5, and $\mathbf{1 0}$ were prepared as previously described. ${ }^{1,2}$ Azide-containing aminoglycoside (7) was prepared with minor modifications of a previously reported procedure. ${ }^{3}$
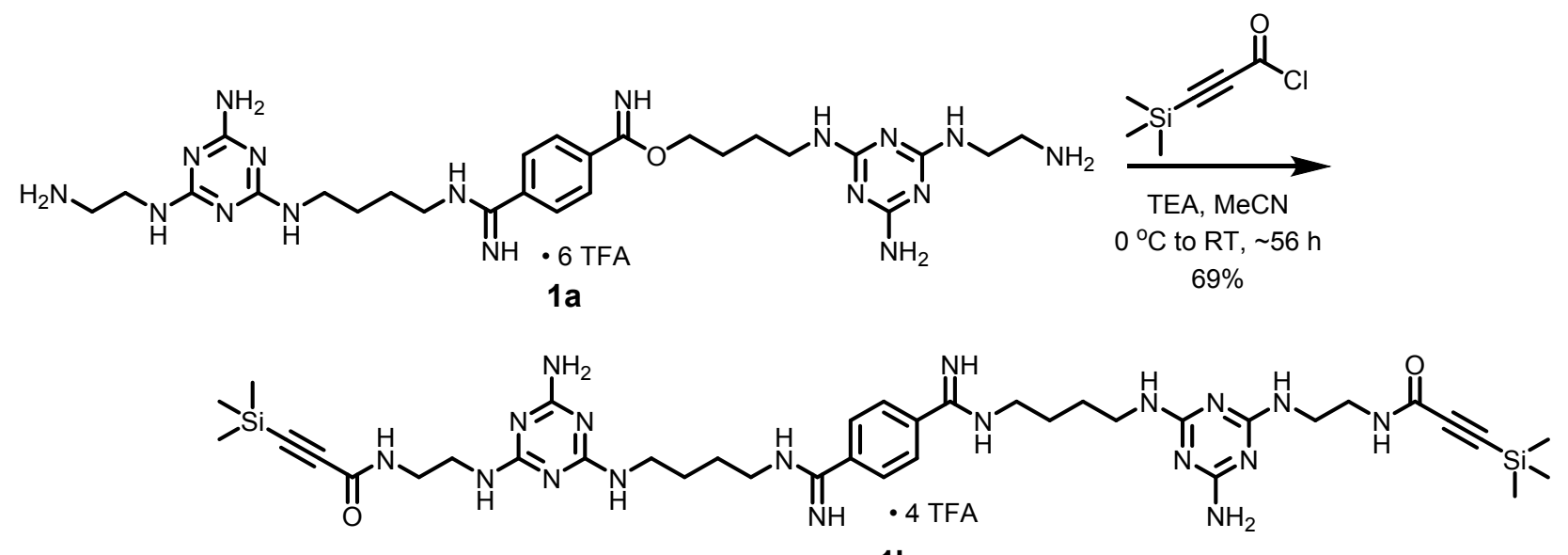

$1 \mathrm{~b}$

Compound 1b. Compound 1a was synthesized as reported previously. ${ }^{1}$ To a $20 \mathrm{~mL}$ vial was added $19.99 \mathrm{mg}(24.1 \mu \mathrm{mol}) \mathbf{1 a}$ and $2.5 \mathrm{~mL}$ acetonitrile. The resulting white suspension was cooled to $0{ }^{\circ} \mathrm{C}$. To the vial was added $27 \mu \mathrm{L}(0.2 \mathrm{mmol})$ triethylamine and the suspension was stirred for an additional $10 \mathrm{~min}$. In a separate vessel was mixed $16.96 \mathrm{mg}$ (106 $\mu \mathrm{mol})$ 3- 
(trimethylsilyl)propioloyl chloride and $1 \mathrm{~mL}$ acetonitrile and the resulting clear solution was added to the $20 \mathrm{~mL}$ vial. The resulting brown solution was warmed to room temperature slowly and stirred for about $56 \mathrm{~h}$ under nitrogen atmosphere. TLC was used to monitor reaction progress (9 MeOH:1 $\mathrm{NH}_{4} \mathrm{OH}$, potassium permanganate stain, $\left.\mathrm{R}_{\mathrm{f}} 0.05\right)$. The solvents were removed in vacuo to obtain a brown solid that was purified via preparative HPLC (gradient $\mathrm{H}_{2} \mathrm{O}(0.1 \%$ TFA):MeCN (0.1\% TFA) from 100:0 to 0:100) to yield $22.0 \mathrm{mg}$ (69\%) of the title compound as a tan, crystalline solid TFA salt. ${ }^{1} \mathrm{H}$ NMR $\left(600 \mathrm{MHz}, \mathrm{DMSO}-d_{6}\right) \delta 9.54$ (bs, $\left.2 \mathrm{H}\right), 9.13$ (bs, $\left.2 \mathrm{H}\right), 8.73$ (bs, 2H), 7.82 (bs, 1H), 7.67 (bs, 1H), 7.47 (bm, 2H), 7.41 (bs, 4H), 7.35 (s, 4H), 2.99 (bm, 2H), 2.87 (bm, 8H), 2.75 (bm, 2H), $2.42(\mathrm{bm}, 4 \mathrm{H}), 1.06(\mathrm{bm}, 8 \mathrm{H}), 0.59(\mathrm{~m}, 18 \mathrm{H})$. LR-ESI MS (m/z) calcd for $\mathrm{C}_{24} \mathrm{H}_{38} \mathrm{~N}_{6} \mathrm{O}_{2} \mathrm{Si}_{2}{ }^{2+}$ $[\mathrm{M}+\mathrm{H}]$ 857.5; found 857.2.
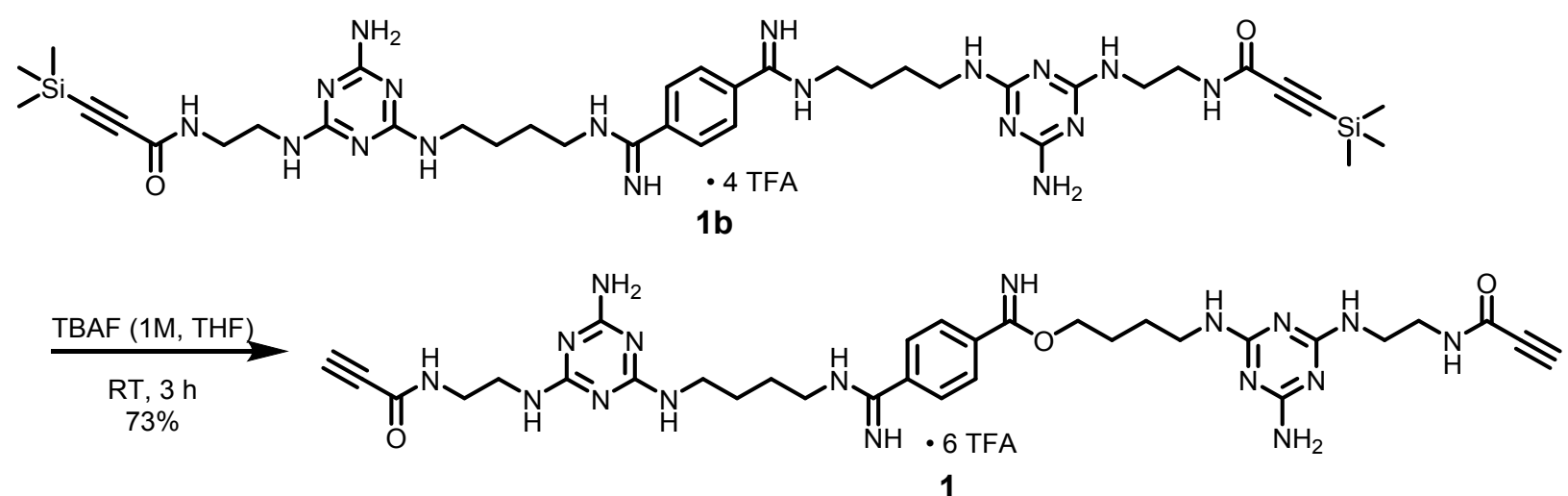

Compound 1. To a $20 \mathrm{~mL}$ vial was added $22.0 \mathrm{mg}(16.8 \mu \mathrm{mol}) \mathbf{1 b}$ and $140 \mu \mathrm{L}(140 \mu \mathrm{mol}) 1 \mathrm{M}$ tetrabutylammonium fluoride in THF and $1.00 \mathrm{~mL}$ DI water. The resulting clear solution was stirred at RT for $3 \mathrm{~h}$ and dried in vacuo to obtain a white solid that was purified via preparative HPLC (gradient $\mathrm{H}_{2} \mathrm{O}$ (0.1\% TFA):MeCN (0.1\% TFA) from 100:0 to 0:100) to yield $19.6 \mathrm{mg}$ (73\%) of the title compound as a tan solid TFA salt. ${ }^{1} \mathrm{H}$ NMR $\left(600 \mathrm{MHz}, d_{2} \mathrm{O}\right) \delta 7.81(\mathrm{~s}, 4 \mathrm{H}), 3.69(\mathrm{bm}, 4 \mathrm{H})$, $3.50(\mathrm{bm}, 8 \mathrm{H}), 3.40$ (bs, 2H), $3.21(\mathrm{bm}, 4 \mathrm{H}), 1.77(\mathrm{bm}, 4 \mathrm{H}), 1.70(\mathrm{bm}, 4 \mathrm{H}) .{ }^{13} \mathrm{C} \mathrm{NMR}\left(600 \mathrm{MHz}, \mathrm{D}_{2} \mathrm{O}\right)$ $\delta 161.80,161.03,160.90 *, 160.66 *, 160.45 *, 160.43 *, 160.19 *, 158.74,156.02,153.99,131.02$, 126.28, 116.93*, 115.00*, 113.07*, 111.13*, 52.79, 44.41, 40.43, 37.93, 36.76, 35.88, 23.43, 21.79. *TFA peaks. LR-ESI MS $(m / z)$ calcd for $\mathrm{C}_{32} \mathrm{H}_{46} \mathrm{~N}_{18} \mathrm{O}_{2}{ }^{2+}[\mathrm{M}+2 \mathrm{H} / 2]$ 357.2; found 357.6. Compound $99 \%$ pure by analytical HPLC (retention time $3.69 \mathrm{~min}$ ).
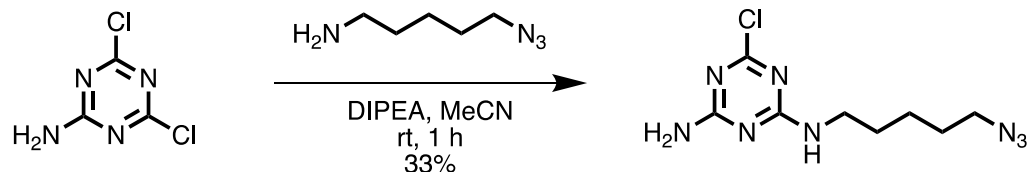

$6 \mathbf{a}$

Compound 6a. To a $50 \mathrm{~mL}$ round bottom flask was added $1.26 \mathrm{~g}$ (7.6 mmol) 2-amino-4,6dichloro-1,3,5-triazine and a magnetic stir bar. The solid was dissolved in $10 \mathrm{~mL}$ acetonitrile. To the flask was added $0.975 \mathrm{~g}(7.6 \mathrm{mmol})$ 5-azidopentylamine in $10 \mathrm{~mL}$ acetonitrile and $1.3 \mathrm{~mL}$ (7.6 mmol) $\mathrm{N}, \mathrm{N}$-diisopropyl ethyl amine dropwise. The reaction was stirred at room temperature for $1 \mathrm{~h}$. The suspension was filtered to give $0.637 \mathrm{~g} \mathrm{(33 \% )} \mathrm{of} 6 \mathrm{a}$ as a white solid. The crude product 
was used in next reaction without further purification. ${ }^{1} \mathrm{H}$ NMR $\left(500 \mathrm{MHz}\right.$, DMSO- $\left.d_{6}\right) \delta 7.75-7.03$ $(\mathrm{m}, 3 \mathrm{H}), 3.32-3.30(\mathrm{~m}, 2 \mathrm{H}), 3.19(\mathrm{p}, \mathrm{J}=6.5,2 \mathrm{H}), 1.57-1.45(\mathrm{~m}, 4 \mathrm{H}), 1.35-1.29(\mathrm{~m}, 2 \mathrm{H})$. LR-ESI MS $(\mathrm{m} / z)$ calcd for $\mathrm{C}_{8} \mathrm{H}_{14} \mathrm{ClN}_{8}{ }^{+}\left[\mathrm{M}+\mathrm{H}^{+}\right]$257.1; found 257.2.

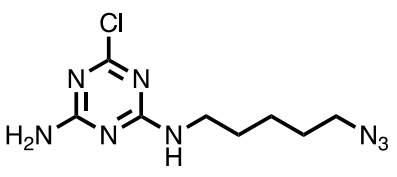

$6 a$

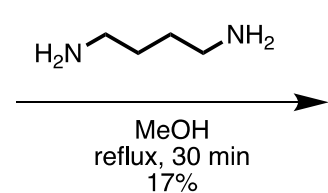

$17 \%$

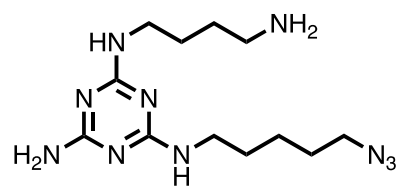

$6 b$

Compound $\mathbf{6 b}$. To a $100 \mathrm{~mL}$ round bottom flask was added $1.25 \mathrm{~mL}$ 1,4-diaminobutane (12.4 $\mathrm{mmol}$ ) and $10 \mathrm{~mL}$ methanol. The solution was heated to $90{ }^{\circ} \mathrm{C}$ (reflux). Compound $6 \mathrm{a}(0.637 \mathrm{~g}$, $2.5 \mathrm{mmol}$ ) was added portion-wise as a white solid over 10 min the flask neck was rinsed with additional methanol. The reaction was stirred at reflux for $30 \mathrm{~min}$. The solvent and remaining diaminobutane was removed by rotary evaporation. The crude product was purified by reversephase $\mathrm{C}_{18}$ column chromatography (9:1 to 7:3 v/ $\left.\mathrm{v} \mathrm{H}_{2} \mathrm{O}: \mathrm{MeOH}\right)$ and by normal-phase silica column chromatography (9:1 to 4:1 v/v DCM:MeOH) to yield $130 \mathrm{mg}$ of $6 \mathbf{b}$ as a while solid (17\% yield). ${ }^{1} \mathrm{H}$ NMR (500 MHz, DMSO- $\left.d_{6}\right) \delta 7.85$ (bs, 2H), 7.79-6.08 (m, 4H), 3.38-3.34 (m, 2H), 3.31-3.27 (m, $2 \mathrm{H}), 3.25-3.18(\mathrm{~m}, 2 \mathrm{H}), 2.81-2.73(\mathrm{~m}, 2 \mathrm{H}), 1.59-1.45(\mathrm{~m}, 8 \mathrm{H}), 1.35-1.29(\mathrm{~m}, 2 \mathrm{H})$. LR-ESI MS $(\mathrm{m} / \mathrm{z})$ calcd for $\mathrm{C}_{12} \mathrm{H}_{25} \mathrm{~N}_{10}{ }^{+}\left[\mathrm{M}+\mathrm{H}^{+}\right]$309.2; found 309.4.<smiles>N#CCCCCCNc1nc(N)nc(NCCCCN)n1</smiles>

6b

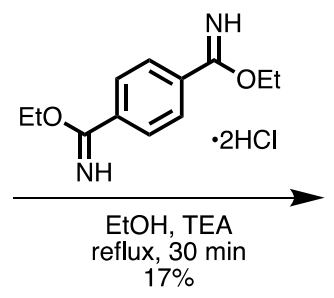

$$
\mathrm{H}_{2}
$$

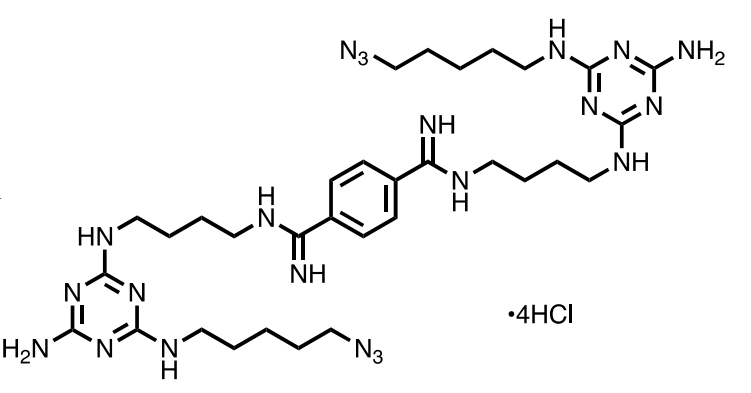

6

Compound $\mathbf{6}$. To an oven-dried $50 \mathrm{~mL}$ round bottom flask was added $1.20 \mathrm{~g}(3.5 \mathrm{mmol})$ diethyl terephthalimidate dihydrochloride and $10 \mathrm{~mL}$ dry ethanol. When the solid was fully dissolved, $1.2 \mathrm{~mL}(8.6 \mathrm{mmol})$ trimethylamine was added dropwise to give a clear solution. A solution of 2.60 $\mathrm{g}$ of compound $\mathbf{6 b}(8.6 \mathrm{mmol})$ in $6 \mathrm{~mL}$ ethanol was added dropwise to the solution. The reaction was stirred at room temperature for $24 \mathrm{~h}$. The solvent was removed by rotary evaporation and the crude solid was purified by reverse-phase chromatography (CombiFlash, 80 g C18 column, 0$50 \%(\mathrm{v} / \mathrm{v}) \mathrm{MeOH}$ in $\mathrm{H}_{2} \mathrm{O}$ with $0.1 \% \mathrm{HCl}$ ). The fractions containing product were combined to yield $1.35 \mathrm{~g}$ of compound 6 as a white $\mathrm{HCl}$ salt $(47 \%) .{ }^{1} \mathrm{H} \mathrm{NMR}\left(500 \mathrm{MHz}, \mathrm{DMSO}-d_{6}\right) \delta 10.31(\mathrm{bs}, 2 \mathrm{H})$, $9.84(\mathrm{~s}, 2 \mathrm{H}), 9.46(\mathrm{~s}, 4 \mathrm{H}), 8.49-8.41(\mathrm{~m}, 2 \mathrm{H}), 8.10-7.91(\mathrm{~m}, 8 \mathrm{H}), 3.52-3.48(\mathrm{~m}, 4 \mathrm{H}), 3.38-3.25(\mathrm{~m}$, $12 \mathrm{H}), 1.74-1.61(\mathrm{~m}, 8 \mathrm{H}), 1.58-1.49(\mathrm{~m}, 8 \mathrm{H}), 1.37-1.31(\mathrm{~m}, 4 \mathrm{H})$. LR-ESI MS $(\mathrm{m} / \mathrm{z})$ calcd for $\mathrm{C}_{32} \mathrm{H}_{54} \mathrm{~N}_{22}{ }^{2+}[\mathrm{M}+2 \mathrm{H} / 2] 373.2$; found 373.2 . Compound $96.8 \%$ pure by analytical HPLC (retention time $6.06 \mathrm{~min})$. 
<smiles>N=C(NCCN)c1ccc(C(=N)NCCN)cc1</smiles>

$8 a$

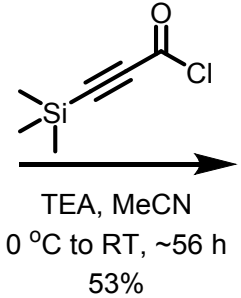

$53 \%$
(T)

$8 \mathrm{~b}$

Compound $\mathbf{8 b}$. Compound $\mathbf{8 a}$ was synthesized using a previously reported procedure. ${ }^{2}$ To a $20 \mathrm{~mL}$ vial was added $19.98 \mathrm{mg}(28.4 \mu \mathrm{mol}) \mathbf{8 a}$ and $1.5 \mathrm{~mL}$ acetonitrile. The resulting white suspension was cooled to $0{ }^{\circ} \mathrm{C}$. To the vial was added $28 \mu \mathrm{L}(0.2 \mathrm{mmol})$ triethylamine and the suspension was stirred for an additional $10 \mathrm{~min}$. In a separate vessel was mixed $18.21 \mathrm{mg}$ (113 $\mu \mathrm{mol}$ ) 3-(trimethylsilyl)propioloyl chloride and $1 \mathrm{~mL}$ acetonitrile and the resulting clear solution was added to the $20 \mathrm{~mL}$ vial. The resulting brown solution was warmed to room temperature slowly and stirred for about $56 \mathrm{~h}$ under nitrogen atmosphere. TLC was used to monitor reaction progress ( $9 \mathrm{MeOH}: 1 \mathrm{NH}_{4} \mathrm{OH}$, potassium permanganate stain, $\left.\mathrm{R}_{\mathrm{f}} 0.05\right)$. The solvents were removed in vacuo to obtain a brown solid that was purified via preparative $\mathrm{HPLC}$ (gradient $\mathrm{H}_{2} \mathrm{O}(0.1 \%$ TFA):MeCN (0.1\% TFA) from 100:0 to 0:100) to obtain $10.5 \mathrm{mg}(53 \%)$ of the title compound as a white, crystalline solid TFA salt. ${ }^{1} \mathrm{H}$ NMR $\left(600 \mathrm{MHz}\right.$, DMSO- $\left.d_{6}\right) \delta 10.22$ (bs, 2H), 9.96 (bs, 2H), 9.60 (bs, 2H), 8.26 (bs, 2H), $8.08(\mathrm{~s}, 4 \mathrm{H}), 3.74(\mathrm{bm}, 4 \mathrm{H}), 3.20$ (bm, 4H), $1.24(\mathrm{~s}, 8 \mathrm{H})^{*}$. *Partially deprotected product leads to smaller trimethylsilyl peak integration. LR-ESI MS $(\mathrm{m} / \mathrm{z})$ calcd for $\mathrm{C}_{24} \mathrm{H}_{38} \mathrm{~N}_{6} \mathrm{O}_{2} \mathrm{Si}_{2}{ }^{2+}[\mathrm{M}+2 \mathrm{H} / 2] 249.13$; found 249.1.

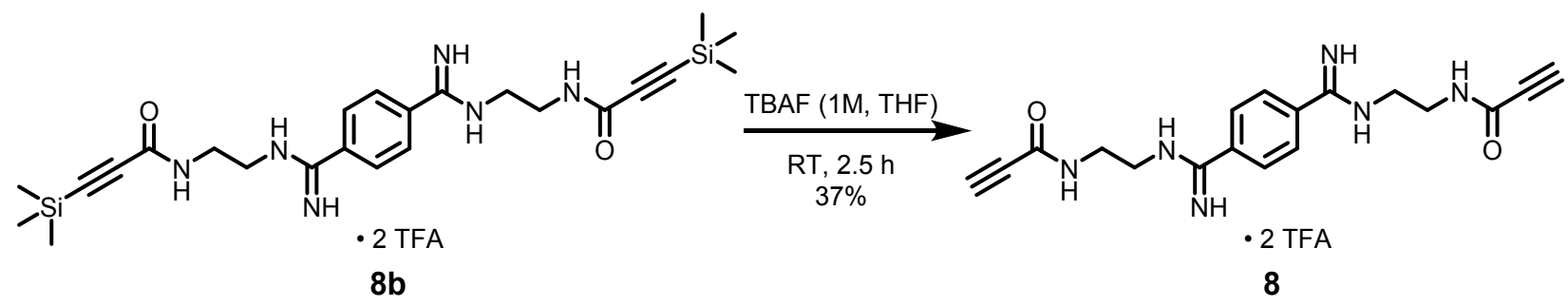

Compound 8. To a $20 \mathrm{~mL}$ vial was added $10.5 \mathrm{mg}(14.5 \mu \mathrm{mol}) 8 \mathrm{~b}$ and $160 \mu \mathrm{L}(160 \mu \mathrm{mol}) 1 \mathrm{M}$ tetrabutylammonium fluoride in THF and $1.00 \mathrm{~mL}$ DI water. The resulting clear solution was stirred at RT for $2.5 \mathrm{~h}$ and dried in vacuo to obtain a white solid that was purified via preparative HPLC (gradient $\mathrm{H}_{2} \mathrm{O}(0.1 \%$ TFA):MeCN (0.1\% TFA) from 100:0 to 0:100) to yield $3.13 \mathrm{mg}(37 \%)$ of the title compound as a white solid TFA salt. ${ }^{1} \mathrm{H} \mathrm{NMR}\left(600 \mathrm{MHz}, D_{2} \mathrm{O}\right) \delta 7.89(\mathrm{~s}, 4 \mathrm{H}), 4.03(\mathrm{bm}$, $4 \mathrm{H}), 3.74(\mathrm{bm}, 4 \mathrm{H}), 3.30(\mathrm{~s}, 2 \mathrm{H}) .{ }^{13} \mathrm{C}$ NMR $\left(600 \mathrm{MHz}, d_{2} \mathrm{O}\right) \delta 165.51,164.30,163.16 *, 162.92 *$, 162.69*, 162.45*, 133.07, 127.44, 119.14*, 117.21*, 115.28*, 113.34*, 44.79, 40.18, 39.28, 36.77. *TFA peaks. LR-ESI MS $(m / z)$ calcd for $\mathrm{C}_{18} \mathrm{H}_{21} \mathrm{~N}_{6} \mathrm{O}_{2}{ }^{+}[\mathrm{M}+\mathrm{H}] 353.41$; found 353.6. 

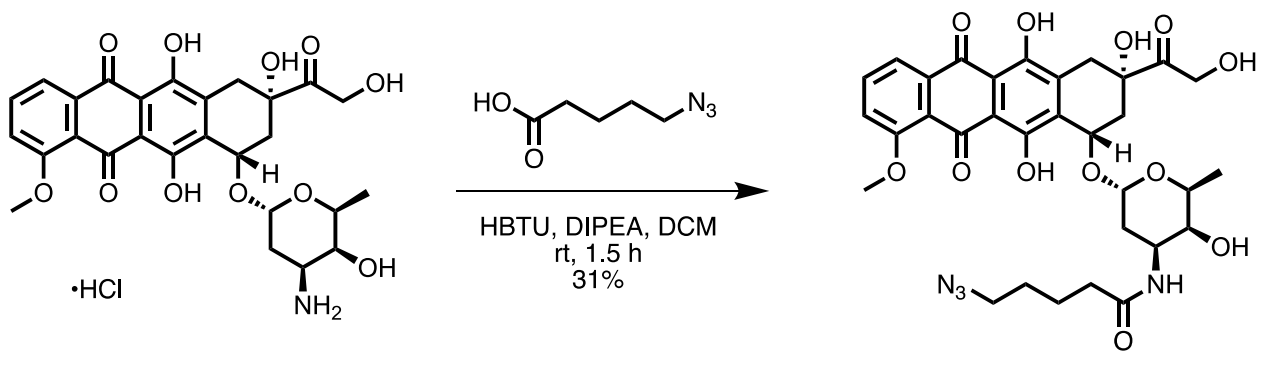

9

Compound 9. To a $300 \mathrm{~mL}$ round-bottom flask was added $120 \mathrm{mg}(0.207 \mathrm{mmol})$ doxorubicin$\mathrm{HCl}$ and $80 \mathrm{~mL}$ dry DCM. A $20 \mathrm{~mL}$ vial was purged and filled with nitrogen. To the vial was added $118 \mathrm{mg}(0.824 \mathrm{mmol})$ of 5 -azidovaleric acid, $206 \mathrm{mg}(0.543 \mathrm{mmol})$ of HBTU, and $10 \mathrm{~mL}$ of DCM. The mixture was stirred at room temperature. After $10 \mathrm{~min}$, the HBTU-carboxylic acid solution was added to the round-bottom flask. The vial was washed with $10 \mathrm{~mL}$ of dry DCM. To the flask was added $600 \mu \mathrm{L}(3.44 \mathrm{mmol}) \mathrm{N}, \mathrm{N}$-diisopropyl ethyl amine dropwise, and the reaction was stirred at room temperature for $1.5 \mathrm{~h}$. The reaction mixture was washed twice with DI water and dried over sodium sulfate before removing the solvent in vacuo. The crude product was purified by flash chromatography (silica gel, $2-15 \% \mathrm{v} / \mathrm{v} \mathrm{MeOH}$ in DCM). The product-containing fractions were combined and the solvent removed in vacuo to yield $43 \mathrm{mg}(31 \%)$ of 9 as a red solid. ${ }^{1} \mathrm{H}$ NMR $\left(500 \mathrm{MHz}\right.$, DMSO- $\left.d_{6}\right) \delta 13.99(\mathrm{~s}, 1 \mathrm{H}), 13.23(\mathrm{~s}, 1 \mathrm{H}), 7.89-7.84(\mathrm{~m}, 2 \mathrm{H}), 7.61(\mathrm{~d}, J=6.2,1 \mathrm{H})$, $7.52(\mathrm{~d}, J=8.1,1 \mathrm{H}), 5.41(\mathrm{~s}, 1 \mathrm{H}), 5.21(\mathrm{~s}, 1 \mathrm{H}), 4.91(\mathrm{bs}, 1 \mathrm{H}), 4.84(\mathrm{t}, J=5.9,1 \mathrm{H}), 4.73(\mathrm{~d}, J=5.9$, $1 \mathrm{H}), 4.58(\mathrm{~d}, J=5.8,2 \mathrm{H}), 4.17(\mathrm{q}, J=6.5,1 \mathrm{H}), 3.96(\mathrm{~s}, 2 \mathrm{H}), 3.40(\mathrm{~d}, J=5.2,1 \mathrm{H}), 3.31(\mathrm{~s}, 2 \mathrm{H}), 3.27$ $(\mathrm{t}, J=6.5,2 \mathrm{H}), 2.98(\mathrm{~d}, J=18,1 \mathrm{H}), 2.90(\mathrm{~d}, J=18,1 \mathrm{H}), 2.20(\mathrm{~d}, J=13,1 \mathrm{H}), 2.12-2.06(\mathrm{~m}, 2 \mathrm{H}), 1.84$ (dt, $J=3.6$ and $13,1 \mathrm{H}), 1.47-1.40(\mathrm{~m}, 5 \mathrm{H}), 1.23(\mathrm{bs}, 1 \mathrm{H}), 1.13(\mathrm{~d}, J=6.3,3 \mathrm{H}) .{ }^{13} \mathrm{C}$ NMR $\delta 214.2$, $186.9,186.8,171.5,161.2,156.6,155.0,136.6,136.0,135.0,134.5,120.4,120.1,119.41,111.2$, 111.1, 100.9, 75.4, 70.4, 68.6, 67.2, 64.2, 57.0, 50.8, 45.3, 37.1, 35.0, 32.5, 30.2, 28.2, 23.0, 17.49. LR-ESI MS $(\mathrm{m} / \mathrm{z})$ calcd for $\mathrm{C}_{32} \mathrm{H}_{37} \mathrm{~N}_{4} \mathrm{O}_{12}{ }^{+}[\mathrm{M}+\mathrm{H}] 669.2$; found 669.7 . Compound was $92 \%$ pure by analytical HPLC (retention time: $7.20 \mathrm{~min}$ ).<smiles>COC(=O)c1nc(Cl)c(Cl)nc1N</smiles>

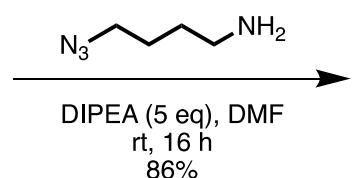

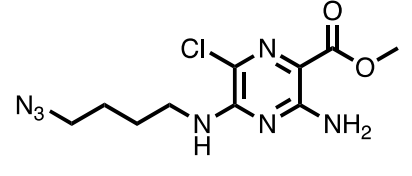

$11 \mathrm{a}$

Compound 11a. To a $15 \mathrm{~mL}$, oven-dried round-bottom flask was added $0.081 \mathrm{~g}(0.36 \mathrm{mmol})$ methyl-3-amino-5,6-dichloropyrazine-2-carboxylate followed by $2.0 \mathrm{~mL}$ dry DMF. To the resulting dark brown solution was added $0.31 \mathrm{~mL}(1.8 \mathrm{mmol}) \mathrm{N}, \mathrm{N}$-diisopropyl ethyl amine and the mixture was stirred for $5 \mathrm{~min}$. In a separate vessel was combined $62 \mathrm{mg}(0.54 \mathrm{mmol})$ 4azidobutan-1-amine and $0.80 \mathrm{~mL}$ dry DMF and the resulting light tan solution was added to the $15 \mathrm{~mL}$ round-bottom flask dropwise. The dark brown solution was stirred at room temperature for about $20 \mathrm{~h}$. Reaction progress was monitored by TLC (5:1 v/v Hex:EtOAc, $\left.R_{f}=0.2\right)$. The dark brown mixture was concentrated in vacuo to obtain a brown residue that was partitioned 
between $50 \mathrm{~mL}$ each of DI water and ethyl acetate. The organic layer was washed with water (3 $\times 50 \mathrm{~mL}$ ) and saturated brine $(2 \times 50 \mathrm{~mL})$ and dried over sodium sulfate. The light yellow, transparent liquid was concentrated in vacuo to afford $95 \mathrm{mg}(86 \%)$ of 11a as a brown residue. ${ }^{1} \mathrm{H}$ NMR $\left(500 \mathrm{MHz}, \mathrm{CdCl}{ }_{3}\right) \delta 5.53(\mathrm{t}, J=5.9,1 \mathrm{H}), 3.83(\mathrm{~s}, 3 \mathrm{H}), 3.43(\mathrm{q}, J=6.6,2 \mathrm{H}), 3.29(\mathrm{t}, J=6.4$, $2 \mathrm{H}), 1.68(\mathrm{~m}, 2 \mathrm{H}), 1.61(\mathrm{~m}, 2 \mathrm{H}), 1.56(\mathrm{~m}, 2 \mathrm{H}) .{ }^{13} \mathrm{C} \mathrm{NMR}\left(500 \mathrm{MHz}, \mathrm{CdCl}_{3}\right) \delta 166.5,155.5,151.6$, 121.4, 110.4, 52.1, 51.1, 40.7, 26.5, 26.3. LR-ESI MS $(\mathrm{m} / \mathrm{z})$ calcd for $\mathrm{C}_{10} \mathrm{H}_{15} \mathrm{ClN}_{7} \mathrm{O}_{2}{ }^{+}\left[\mathrm{M}^{+} \mathrm{H}^{+}\right] 300.1$; found 300.1 .

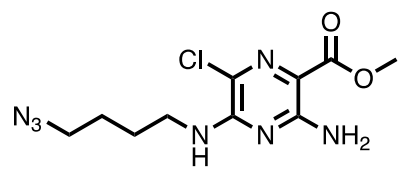

$11 a$

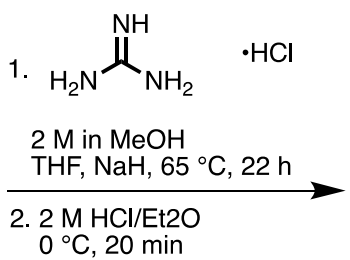

$13 \%$

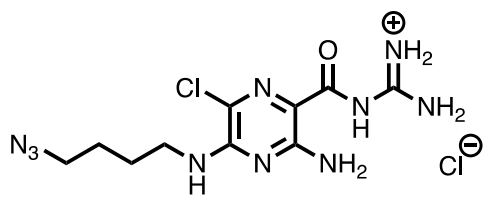

11

Compound 11. To a $10 \mathrm{~mL}$ round-bottom flask was added $71.1 \mathrm{mg}(0.237 \mathrm{mmol}) 11 \mathrm{a}$ and 1.75 $\mathrm{mL}$ THF (0.10 M total reaction concentration). In a separate vessel was mixed $114 \mathrm{mg}$ (1.19 mmol) guanidine hydrochloride and $0.60 \mathrm{~mL}$ methanol and added the solution to the $10 \mathrm{~mL}$ roundbottom flask. The resulting light orange solution was stirred at $65^{\circ} \mathrm{C}$ for $4 \mathrm{~h}$ and $54.7 \mathrm{mg}(2.28$ $\mathrm{mmol}$ ) sodium hydride was added. The light orange solution was stirred at $65^{\circ} \mathrm{C}$ for $18 \mathrm{~h}$. TLC was used to monitor reaction progress (9:1 v/v DCM:MeOH, $\left.R_{f} 0.3\right)$. The reaction was quenched with $6 \mathrm{~mL}$ methanol, stirred for $30 \mathrm{~min}$, diluted with $50 \mathrm{~mL} \mathrm{DCM}$, and washed with $50 \mathrm{~mL}$ saturated brine to obtain a white precipitate that was removed by filtration. The filtrate was transferred to a separatory funnel, the organic layer was removed, and the aqueous layer was washed with 10 $\mathrm{mL}$ DCM. The organic layers were concentrated in vacuo to obtain a yellow solid that was purified using a $0.5^{\prime \prime} \times 6^{\prime \prime}$ silica gel column, wet loading the product dissolved in DCM, in gradient of 95:5 v/v DCM:MeOH to 70:30 v/v DCM:MeOH. The fractions containing product were combined and concentrated in vacuo. The resulting pink solid was dissolved in methanol and cooled to $0{ }^{\circ} \mathrm{C}$. The colorless solution was stirred on ice and $1.0 \mathrm{~mL} 2 \mathrm{M} \mathrm{HCl}$ in ether was added dropwise. The resulting yellow suspension was stirred for $20 \mathrm{~min}$ and triturated with cold ether $(3 \times 10 \mathrm{~mL})$. The white precipitate was dried in vacuo to yield $9.69 \mathrm{mg}$ (13\% over 2 steps) of the title compound as a white solid $\mathrm{HCl}$ salt. ${ }^{1} \mathrm{H}$ NMR $\left(500 \mathrm{MHz}, \mathrm{DMSO}-d_{6}\right) \delta 10.60(\mathrm{~s}, 1 \mathrm{H}), 8.58(\mathrm{bs}, 2 \mathrm{H}), 8.31(\mathrm{bs}, 2 \mathrm{H})$, $8.01(\mathrm{t}, J=5.8,1 \mathrm{H}), 7.54(\mathrm{bs}, 2 \mathrm{H}), 3.42(\mathrm{q}, J=6.7,2 \mathrm{H}), 3.38(\mathrm{t}, J=6.7,2 \mathrm{H}), 1.64(\mathrm{~m}, 2 \mathrm{H}), 1.57(\mathrm{~m}$, $2 H) .{ }^{13} \mathrm{C}$ NMR $\delta 165.7,156.3,155.5,152.7,120.6,108.6,50.8,40.6,26.2,26.0 .{ }^{1} \mathrm{H}$ NMR $\left(\mathrm{D}_{2} \mathrm{O}\right) \delta$ $3.43(\mathrm{t}, J=6.7,2 \mathrm{H}), 3.31(\mathrm{t}, J=6.5,2 \mathrm{H}), 1.63(\mathrm{~m}, 4 \mathrm{H}) .{ }^{13} \mathrm{C} N M R\left(\mathrm{D}_{2} \mathrm{O}\right) \delta 165.6,155.9,154.9,152.7$, 122.0, 108.3, 50.8, 40.4, 25.4, 25.4. LR-ESI MS $(\mathrm{m} / \mathrm{z})$ calcd for $\mathrm{C}_{10} \mathrm{H}_{16} \mathrm{CIN}_{10} \mathrm{O}^{+}\left[\mathrm{M}+\mathrm{H}^{+}\right] 327.1$; found 327.1. Compound $95.5 \%$ pure by analytical HPLC (retention time $6.049 \mathrm{~min}$ ). Soluble in DMSO and $\mathrm{D}_{2} \mathrm{O}$, stable by NMR over at least $7 \mathrm{~d}$ in $\mathrm{D}_{2} \mathrm{O}$. 

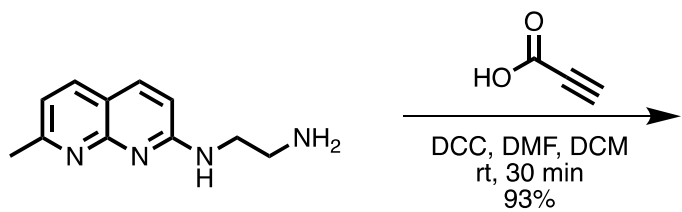<smiles>C#CC(=O)NCCNc1ccc2ccc(C)nc2n1</smiles>

12

Compound 12. To a $50 \mathrm{~mL}$ round bottom flask was added $0.06 \mathrm{~g}(0.3 \mathrm{mmol}) \mathrm{N2}-(2-$ aminoethyl)-1,8-naphthyridine-2,7-diamine and $10 \mathrm{~mL}$ DMF. To a separate vial was added $10 \mathrm{~mL}$ of DCM, $0.12 \mathrm{~g}(0.06 \mathrm{mmol})$ of DCC, and $0.04 \mathrm{~g}(0.06 \mathrm{mmol})$ of propiolic acid. The resulting solution was added to the reaction flask all at once. The mixture was stirred at room temperature for $30 \mathrm{~min}$. The reaction was concentrated using a rotary evaporator. The crude was purified by silica gel column chromatography using a gradient mixture of DCM:MeOH from 98:2 to 95:5 v/v. Fractions containing product were combined and concentrated using a rotary evaporator to give $0.07 \mathrm{~g}(93 \%)$ of 12 as a brown solid. ${ }^{1} \mathrm{H}$ NMR $\left(500 \mathrm{MHz}, \mathrm{CD}_{3} \mathrm{OD}\right): \delta 8.39$ (d, $\left.J=7.9,1 \mathrm{H}\right), 7.97(\mathrm{~d}, J$ $=9.1,1 \mathrm{H}), 7.32(\mathrm{~d}, J=7.9,1 \mathrm{H}), 6.97(\mathrm{~d}, J=9.0,1 \mathrm{H}), 3.71(\mathrm{t}, J=6.1,2 \mathrm{H}), 3.6(\mathrm{~s}, 1 \mathrm{H}), 3.54(\mathrm{t}, J=6.1$, $2 \mathrm{H}), 2.76(\mathrm{~s}, 3 \mathrm{H})$. HR-ESI MS $(\mathrm{m} / \mathrm{z})$ calcd for $\mathrm{C}_{14} \mathrm{H}_{15} \mathrm{~N}_{4} \mathrm{O}^{+}[\mathrm{M}+\mathrm{H}]$ 255.1246; found 255.1238. Compound $93.2 \%$ pure by analytical HPLC (retention time: $4.52 \mathrm{~min}$ ).

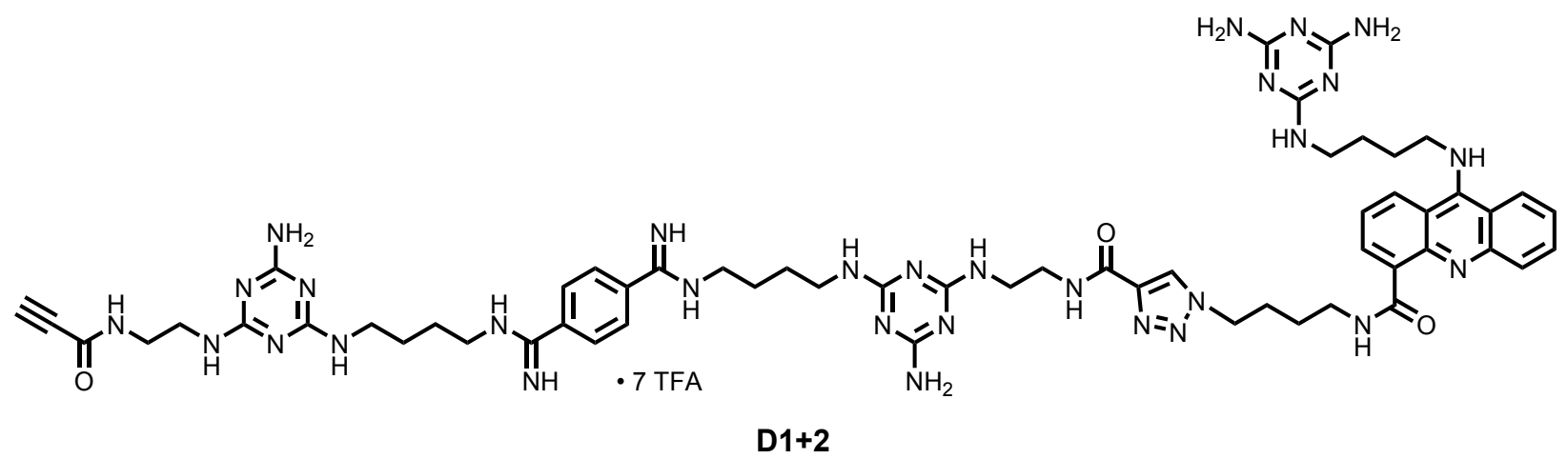

Dimer 1+2. To a $20 \mathrm{~mL}$ vial was added $2.3 \mathrm{mg}(2 \mu \mathrm{mol}) 1$ and $0.9 \mathrm{mg}(1 \mu \mathrm{mol}) 2$ dissolved in 2 $\mathrm{mL} 1: 1 \mathrm{MeOH}: \mathrm{H}_{2} \mathrm{O}$. To the yellow solution was added $1.5 \mathrm{mg}(6 \mu \mathrm{mol})$ copper sulfate pentahydrate and $0.6 \mathrm{mg}(3 \mu \mathrm{mol})$ sodium thiosulfate. The reaction was stirred at room temperature for $48 \mathrm{~h}$. The crude product was run through a basic alumina micro column using $100 \% \mathrm{MeOH}$ to remove the copper. The resulting product was purified using preparative HPLC (gradient $\mathrm{H}_{2} \mathrm{O}$ (0.1\% TFA):MeCN (0.1\% TFA) from $90: 10$ to $\left.0: 100\right)$ to obtain $3.02 \mathrm{mg}(75 \%)$ of the dimer as a yellow solid TFA salt. Analytical HPLC retention time $5.54 \mathrm{~min}$. MALDI MS (m/z) calcd for $\mathrm{C}_{57} \mathrm{H}_{75} \mathrm{~N}_{30} \mathrm{O}_{3}{ }^{+}\left[\mathrm{M}+\mathrm{H}^{+}\right]$1228.43, found 1227.924 . 


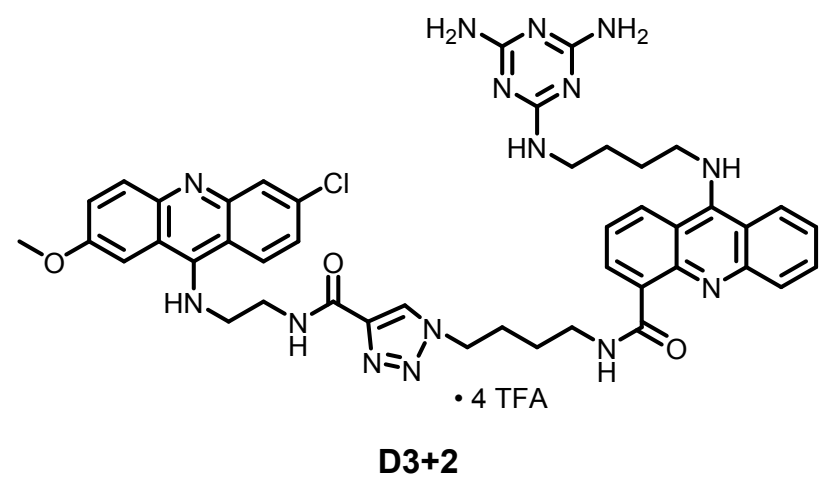

Dimer $\mathbf{3 + 2}$. To a $20 \mathrm{~mL}$ vial was added $10 \mathrm{mg}(21 \mu \mathrm{mol}) 3$ and $16 \mathrm{mg}(21 \mu \mathrm{mol}) 2$ dissolved in $10 \mathrm{~mL} 1: 1 \mathrm{MeOH}: \mathrm{H}_{2} \mathrm{O}$. A $30 \mathrm{mg}$ piece of copper wire was added to the yellow solution and the reaction was stirred at room temperature for $24 \mathrm{~h}$. The crude product was run through a basic alumina micro column using $100 \% \mathrm{MeOH}$ to remove the copper. The resulting product was purified using preparative HPLC (gradient $\mathrm{H}_{2} \mathrm{O}$ (0.1\% TFA):MeCN (0.1\% TFA) from 100:0 to 0:100) to obtain $0.91 \mathrm{mg}(3 \%)$ of the dimer as a yellow solid TFA salt. 97\% pure by analytical HPLC, retention time $6.57 \mathrm{~min} .{ }^{1} \mathrm{H}$ NMR $\left(500 \mathrm{MHz}\right.$, DMSO- $\left.d_{6}\right) \delta 13.78(\mathrm{~d}, J=0.1,2 \mathrm{H}), 10.00(\mathrm{~s}, 1 \mathrm{H}), 9.71$ (s, 1H), $9.27(\mathrm{~s}, 1 \mathrm{H}), 9.11(\mathrm{~s}, 1 \mathrm{H}), 8.67(\mathrm{~s}, 1 \mathrm{H}), 8.65-8.55(\mathrm{~m}, 1 \mathrm{H}), 8.50-8.35(\mathrm{~m}, 2 \mathrm{H}), 8.21-7.40$ $(\mathrm{m}, 12 \mathrm{H}), 6.56(\mathrm{bs}, 4 \mathrm{H}), 4.51(\mathrm{~s}, 2 \mathrm{H}), 4.28(\mathrm{~s}, 2 \mathrm{H}), 4.10(\mathrm{~s}, 2 \mathrm{H}), 4.00(\mathrm{~s}, 3 \mathrm{H}), 3.98-3.88(\mathrm{~m}, 1 \mathrm{H}), 3.79$ $(\mathrm{s}, 4 \mathrm{H}), 1.94(\mathrm{~s}, 4 \mathrm{H}), 1.59(\mathrm{~s}, 4 \mathrm{H}), 1.26(\mathrm{~s}, 2 \mathrm{H})$. MALDI MS (m/z) calcd for $\mathrm{C}_{44} \mathrm{H}_{47} \mathrm{ClN}_{15} \mathrm{O}_{3}{ }^{+}\left[\mathrm{M}+\mathrm{H}^{+}\right]$ 868.37, found 868.278.

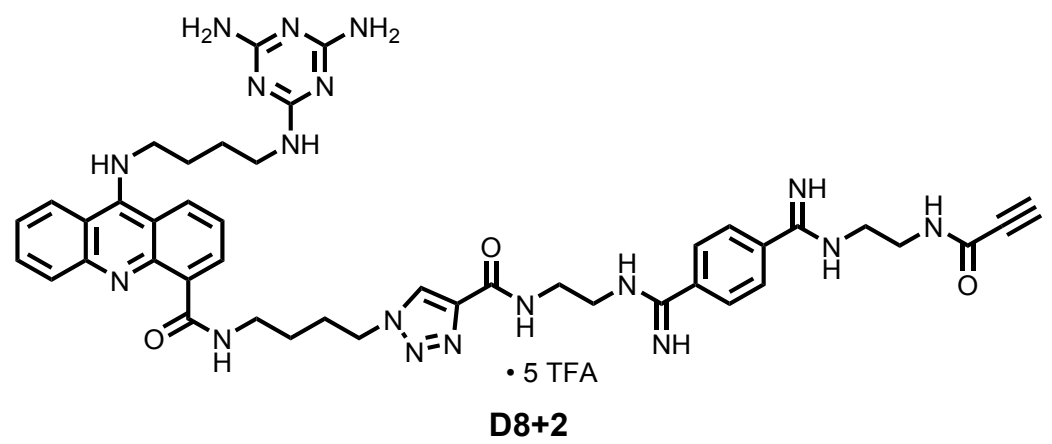

Dimer $8+2$. To a $20 \mathrm{~mL}$ vial was added $1.5 \mathrm{mg}(2.6 \mu \mathrm{mol}) 8$ and $1 \mathrm{mg}(1.3 \mu \mathrm{mol}) 2$ dissolved in $2 \mathrm{~mL} 1: 1 \mathrm{MeOH}: \mathrm{H}_{2} \mathrm{O}$. To the yellow solution was added $1.5 \mathrm{mg}(6 \mu \mathrm{mol})$ copper sulfate pentahydrate and $0.6 \mathrm{mg}(3 \mu \mathrm{mol})$ sodium thiosulfate. The reaction was stirred at room temperature for $24 \mathrm{~h}$. The crude product was run through a basic alumina micro column using $100 \% \mathrm{MeOH}$ to remove the copper. The resulting product was purified using preparative HPLC (gradient $\mathrm{H}_{2} \mathrm{O}(0.1 \%$ TFA): $\mathrm{MeCN}(0.1 \% \mathrm{TFA})$ from $90: 10$ to $0: 100)$ to obtain $1.45 \mathrm{mg}(76 \%)$ of the dimer as a yellow solid TFA salt. Analytical HPLC retention time $5.38 \mathrm{~min} .{ }^{1} \mathrm{H}$ NMR $(600 \mathrm{MHz}$, DMSO-d $\left.d_{6}\right) \delta 9.89(\mathrm{~s}, 1 \mathrm{H}), 7.93(\mathrm{~s}, 1 \mathrm{H}), 7.87(\mathrm{~s}, 2 \mathrm{H}), 7.42(\mathrm{~s}, 4 \mathrm{H}), 7.30(\mathrm{~s}, 4 \mathrm{H}), 7.23(\mathrm{~s}, 2 \mathrm{H}), 7.14(\mathrm{~s}$, $2 \mathrm{H}), 6.33(\mathrm{~s}, 4 \mathrm{H}), 6.26(\mathrm{~s}, 1 \mathrm{H}), 5.33(\mathrm{~s}, 2 \mathrm{H}), 3.76(\mathrm{~s}, 10 \mathrm{H}), 3.52(\mathrm{~s}, 6 \mathrm{H}), 3.02(\mathrm{~s}, 1 \mathrm{H}), 1.25(\mathrm{~s}, 8 \mathrm{H})$ 
*some amines are exchanged. MALDI MS (m/z) calcd for $\mathrm{C}_{43} \mathrm{H}_{52} \mathrm{~N}_{18} \mathrm{O}_{3}{ }^{+}\left[\mathrm{M}+\mathrm{H}^{+}\right]$868.00, found 867.515.

Template-click reactions using $\mathrm{d}(\mathrm{CTG})_{16}, 24$-mer DNA, and buffer

Each in situ click reaction was run in a $0.5 \mathrm{~mL}$ Eppendorf tube. The following is a general procedure performed with $\mathrm{d}(\mathrm{CTG})_{16}$. To each tube was added $75 \mu \mathrm{L}$ nuclease-free water, $1 \mu \mathrm{L} 100$ $\mathrm{mM} \mathrm{KCl}, 1 \mu \mathrm{L} 100 \mathrm{mM} \mathrm{MgCl}, 1 \mu \mathrm{L} 100 \mathrm{mM}$ Tris- $\mathrm{HCl}$ (pH 7.0), and $1 \mu \mathrm{L} 200 \mathrm{mM} \mathrm{CaCl}_{2}$ (1 mM final concentration). The tubes were vortexed to mix. To each reaction tube was added $1 \mu \mathrm{L} 1 \mathrm{mM}$ DNA (10 $\mu \mathrm{M}$ final concentration). The DNA was annealed by heating at $95^{\circ} \mathrm{C}$ for $5 \mathrm{~min}$ and cooling over $90 \mathrm{~min}$ to room temperature. The appropriate azides and alkynes were added to each reaction (10 $\mu \mathrm{L}$ each of $1 \mathrm{mM}$ stock, 25\% (v/v) DMSO, final concentration of each ligand: $100 \mu \mathrm{M}$, $2.5 \%(\mathrm{v} / \mathrm{v}) \mathrm{DMSO}$ ). The reactions were incubated at $37{ }^{\circ} \mathrm{C}$ for up to $7 \mathrm{~d}$. The reactions were monitored by MALDI-TOF Mass Spectrometry. A $10 \mu \mathrm{L}$ aliquot was removed from the reaction tube. To each aliquot was added $2 \mu \mathrm{L}$ of DNase I. The denaturing reaction was incubated at $37^{\circ} \mathrm{C}$ for $30 \mathrm{~min}$ and submitted for MALDI MS. The MALDI plate was spotted with $1 \mu \mathrm{L}$ of the sample and $1 \mu \mathrm{L}$ of DHB matrix, dried, and measured by a technician in the mass spectrometry lab.

\section{Monitoring $\mathrm{d}(\mathrm{CTG})_{16}$-templated click reactions by HPLC}

In situ click reactions for $1+2,1+4,1+9,1+10$, and $1+11$ were performed as described above. Immediately after monomer addition and after one, three, five and seven days, the reactions were denatured using DNase I and analyzed by HPLC (injection volume: $75 \mu \mathrm{L}, 0-100 \% \mathrm{MeCN}$, $0.1 \%$ TFA, flow rate $1.5 \mathrm{~mL} / \mathrm{min}$ ). The concentration of monomers was calculated by fitting the area of the peak to a standard curve. The percent product was calculated as the percent area of the product peak relative to the reactants. 
Table S1. Results from Target-Guided Screen with d(CTG) ${ }_{16}$, Random DNA, or no template (buffer only).

\begin{tabular}{|c|c|c|c|c|}
\hline Reaction & Calcd Mass & $\mathrm{d}(\mathrm{CTG})_{16}$ & Buffer & Random DNA \\
\hline $1+2$ & $1227.4 / 1742.0$ & $1227.8 / 1742.1$ & nd & nd \\
\hline $3+2$ & 868.4 & 868.5 & nd & nd \\
\hline $8+2$ & $867.0 / 1381.6$ & $867.7 / 1382.0$ & nd & nd \\
\hline $12+2$ & 768.9 & 769.6 & nd & nd \\
\hline $1+4$ & $1054.6 / 1396.4$ & $1054.5 / \mathrm{nd}$ & nd & nd \\
\hline $3+4$ & 695.6 & 695.3 & nd & nd \\
\hline $8+4$ & $694.2 / 1036.0$ & $694.4 / \mathrm{nd}$ & nd & nd \\
\hline $12+4$ & 596.1 & nd & nd & nd \\
\hline $1+5$ & 1041.2/ & nd/nd & nd & nd \\
\hline $3+5$ & 584.7 & nd & nd & nd \\
\hline $8+5$ & 680.8 & nd & nd & nd \\
\hline $12+5$ & 584.7 & nd & nd & nd \\
\hline $1+6$ & $1457.8 / 2202.7$ & $\mathrm{nd} / \mathrm{nd}$ & nd & nd \\
\hline $3+6$ & $1098.7 / 1452.5$ & $1098.9 / 1452.0$ & nd & nd \\
\hline $8+6$ & 1097.3/1841.1 & $\mathrm{nd} / \mathrm{nd}$ & nd & nd \\
\hline $12+6$ & $999.2 / 1253.5$ & 999.8/nd & nd & nd \\
\hline $1+7$ & $1277.4 / 1842.0$ & nd/nd & nd & nd \\
\hline $3+7$ & 918.4 & nd & nd & nd \\
\hline $8+7$ & $917.0 / 1481.6$ & $\mathrm{nd} / \mathrm{nd}$ & nd & nd \\
\hline $12+7$ & 818.9 & nd & nd & nd \\
\hline $1+9$ & $1381.5 / 2051.1$ & $1381.6 / \mathrm{nd}$ & nd & nd \\
\hline $3+9$ & 1022.5 & 1022.5 & 1022.3 & 1022.5 \\
\hline $8+9$ & $1021.1 / 1689.7$ & $1021.7 / \mathrm{nd}$ & nd & nd \\
\hline $12+9$ & 923.0 & 923.5 & nd & nd \\
\hline $1+10$ & $995.1 / 1277.5$ & $995.6 / 1277.7$ & nd & nd \\
\hline $3+10$ & 636.12 & nd & nd & nd \\
\hline $8+10$ & $634.7 / 917.0$ & $635.4 / \mathrm{nd}$ & nd & nd \\
\hline $12+10$ & 536.6 & nd & nd & nd \\
\hline $1+11$ & $1040.6 / 1368.3$ & $1039.5 / \mathrm{nd}$ & nd & nd \\
\hline $3+11$ & 681.6 & 682.3 & nd & nd \\
\hline $8+11$ & 680.2 & 679.4 & nd & nd \\
\hline $12+11$ & 582.1 & nd & nd & nd \\
\hline
\end{tabular}




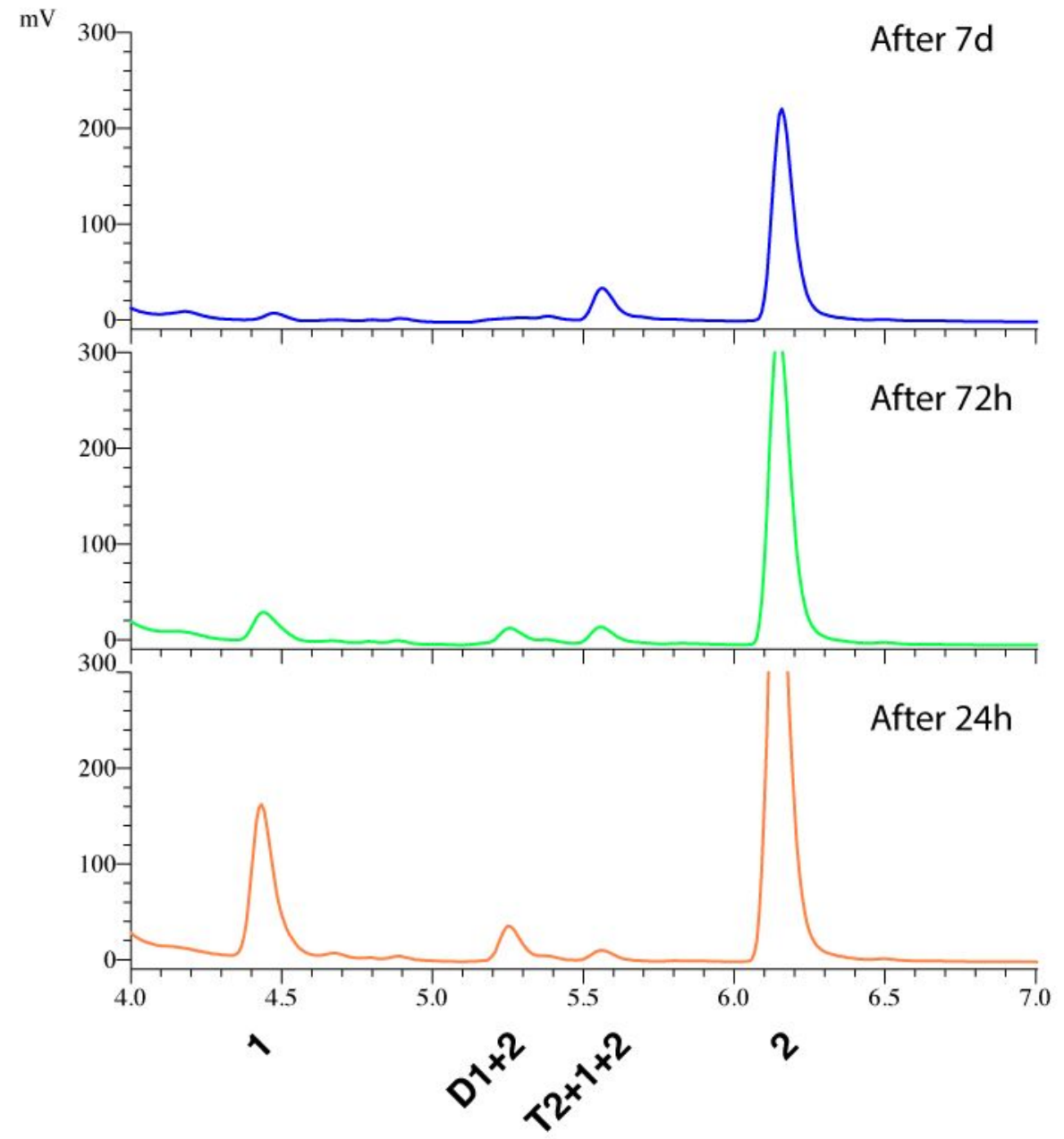

Figure S1. Reaction 1+2 over time monitored by HPLC. 


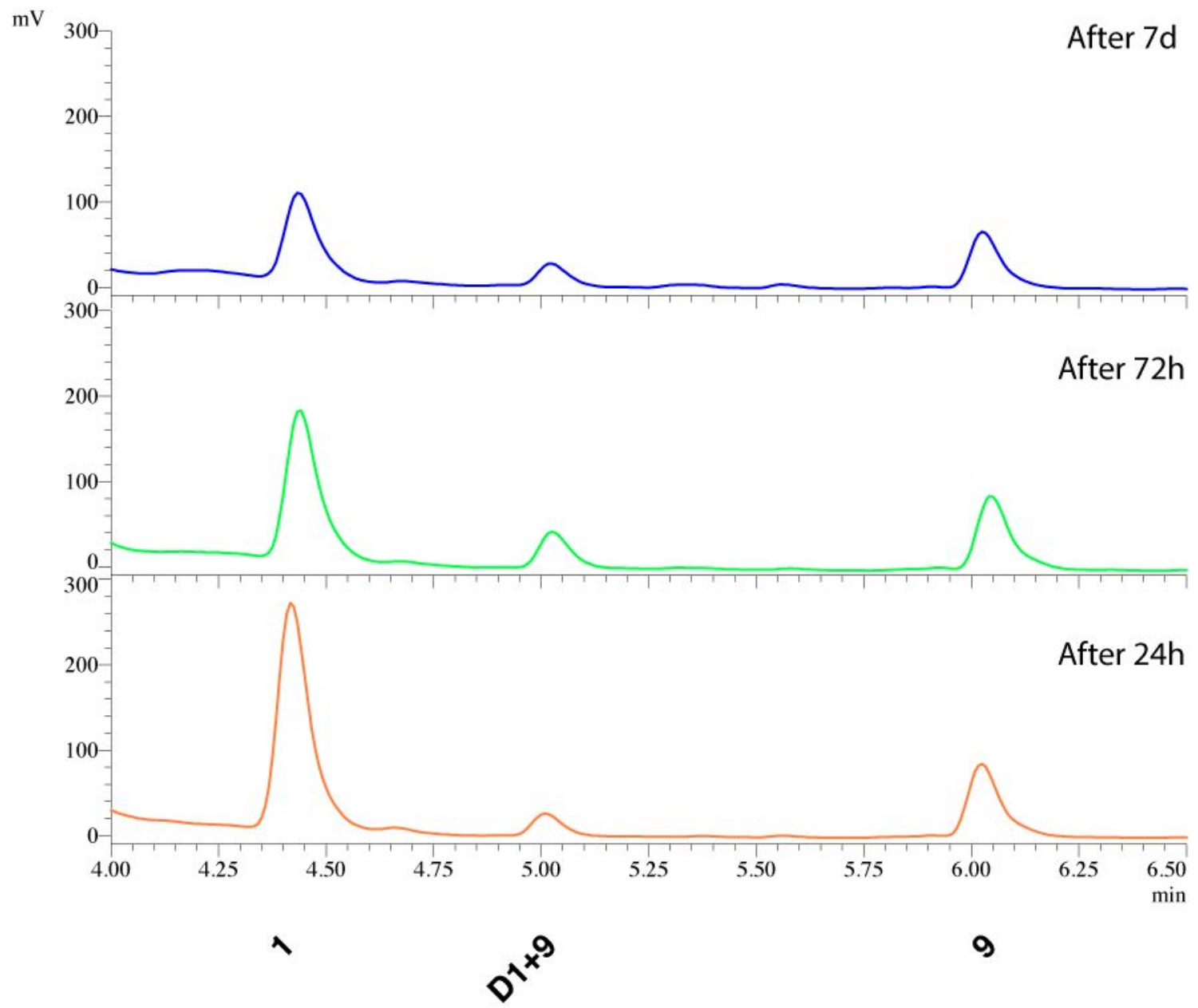

Figure S2. Reaction 1+9 over time monitored by HPLC 

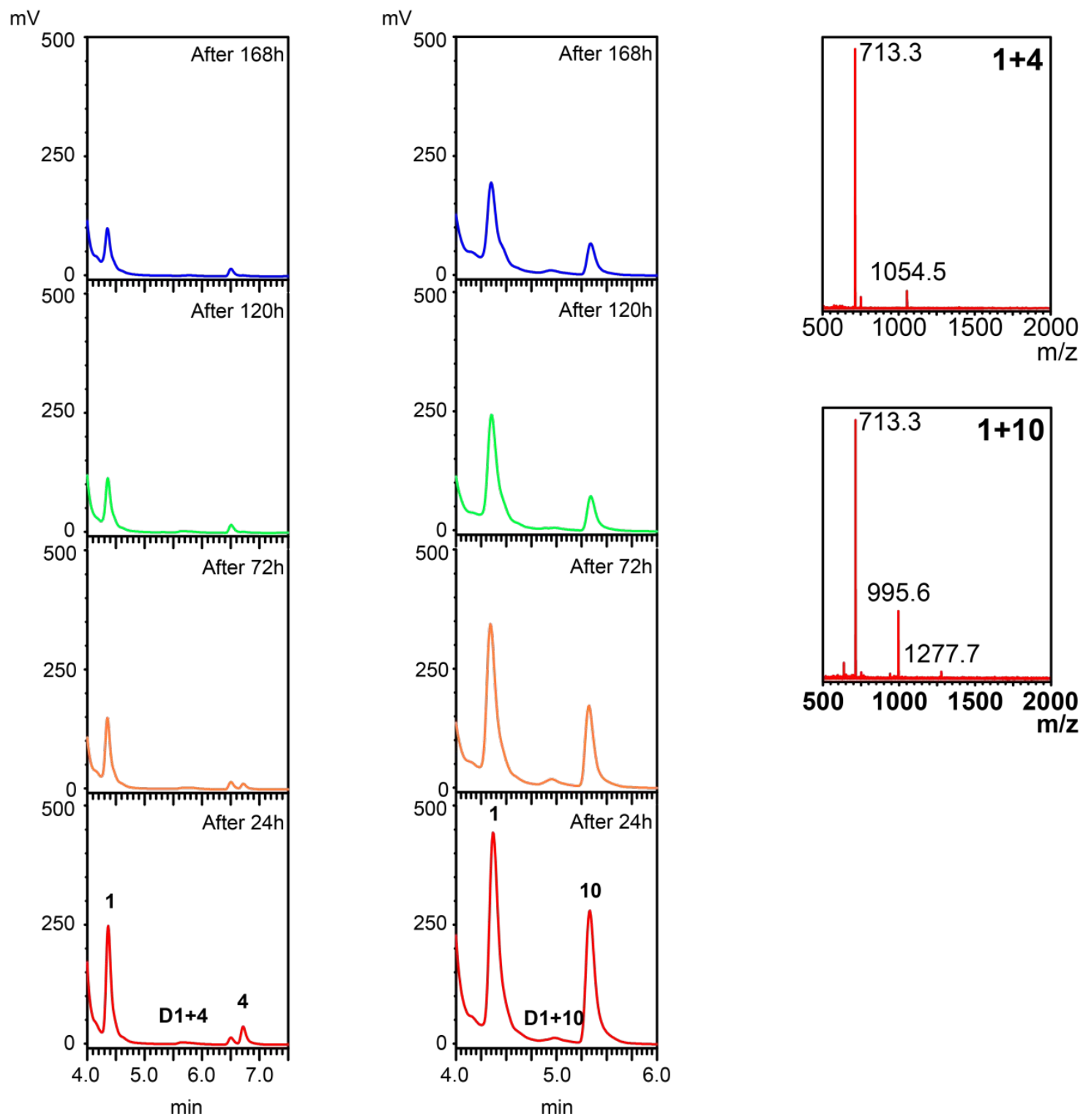

Figure S3. Additional HPLC traces and MS spectra for pairwise click reactions. 

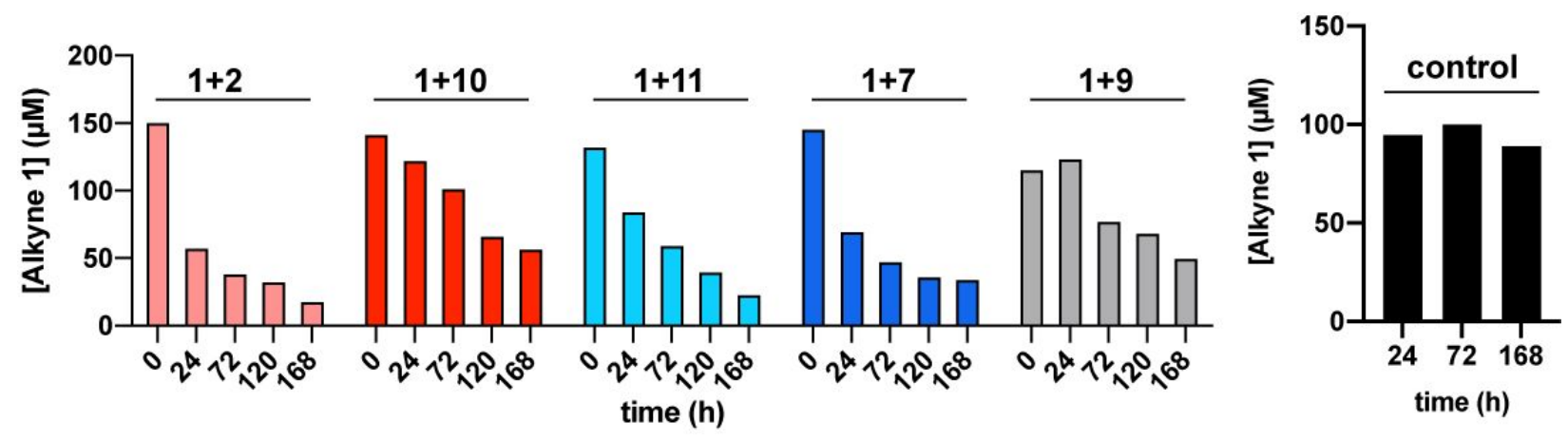

Figure S4. (left) HPLC monitoring of template-assisted click reaction by decrease of alkyne 1. (right) Control experiment with alkyne 1, d(CTG) ${ }_{16}$, and buffer only. DNA was degraded with DNase I prior to HPLC. Alkyne 1 concentration was calculated by fitting the area to a standard curve.

\section{Bidirectional Transcription Inhibition of d(CTG.CAG) $)_{90}$}

E. coli Transformation and Selection with pSP72-CTG90. E. coli were transformed with pSP72CTG90 (plasmid from the Swanson group) containing an ampicillin resistance gene as the selection marker following the protocol for NEB High Efficiency Transformation with the following modifications. NEB Turbo Competent $E$. coli (High Efficiency) cells were thawed on ice. When the cells were thawed, $50 \mu \mathrm{L}$ of cells were added to two $0.5 \mathrm{~mL}$ vials. To each vial was added $2 \mu \mathrm{L}$ of plasmid. The tubes were gently mixed, and the vials were put on ice for $30 \mathrm{~min}$. To two $2 \mathrm{~mL}$ vials were added $950 \mu \mathrm{L}$ of SOC outgrowth media. After $30 \mathrm{~min}$, the vials containing the $E$. coli and plasmid were heat shocked for $30 \mathrm{~s}$ at $42{ }^{\circ} \mathrm{C}$ and placed on ice for $5 \mathrm{~min}$. The cells and plasmid were added to the tubes containing the SOC media. The vials were incubated at $37^{\circ} \mathrm{C}$ for $1 \mathrm{~h}$. The cells $(50 \mu \mathrm{L}$ or $100 \mu \mathrm{L}$ ) were added to agar plates containing ampicillin. The plates were incubated at $37^{\circ} \mathrm{C}$ for $12-14 \mathrm{~h}$. From each plate one colony was collected for growth in LB broth (10 mL) with ampicillin $(10 \mu \mathrm{L})$ in a lightly capped $50 \mathrm{~mL}$ centrifuge tube at $37^{\circ} \mathrm{C}$ for $14 \mathrm{~h}$. The tubes were put on ice and centrifuged for $20 \mathrm{~min}$ at $5000 \mathrm{rpm}$ and $4{ }^{\circ} \mathrm{C}$. The media was decanted off and the cell pellets were frozen until plasmid extraction.

pSP72-CTG90 Plasmid Extraction and Purification. The plasmids were extracted from E. coli using the QIAPrep Spin Mini Kit Protocol with the following changes. The cell pellets from the $E$. coli transformation were resuspended in $500 \mu \mathrm{L}$ of Buffer P1 and transferred to a $2 \mathrm{~mL}$ Eppendorf tube. To each $2 \mathrm{~mL}$ tube was added $500 \mu \mathrm{L}$ of Buffer P2. The tubes were inverted 4-6 times until the solution became clear. To each tube was added $700 \mu \mathrm{L}$ of Buffer N3 and the tubes were inverted 4-6 times. The tubes were centrifuged for $10 \mathrm{~min}$ at 13,000 rpm. The supernatant was added to the QIAprep 2.0 spin column and centrifuged for $1 \mathrm{~min}$ at 13,000 rpm, discarding the flow through. The column was washed by adding $500 \mu \mathrm{L}$ buffer PB and centrifuged for 1 min at $13,000 \mathrm{rpm}$, discarding the flow through. The column was washed with $750 \mu \mathrm{L}$ buffer PE and centrifuged for $1 \mathrm{~min}$ at 13,000 rpm, discarding the flow through. The column was dried for $1 \mathrm{~min}$ by centrifuging at $13,000 \mathrm{rpm}$ to remove any residual wash buffer. The DNA was eluted from the 
column by added the spin column to a clean labeled $1.5 \mathrm{~mL}$ Eppendorf tube, adding $50 \mu \mathrm{L}$ buffer EB (10 mM Tris-Cl, pH 8.5). The buffer was incubated on the column for $1 \mathrm{~min}$. The column and tube were centrifuged for $1 \mathrm{~min}$. The DNA concentration was measured on a Thermo Scientific NanoDrop using the extension coefficient for DNA.

Plasmid Linearization. Plasmids containing 90 CTG/CAG repeats were linearized using BamHI or EcoRI restriction enzymes to yield fragments with T7 or SP6 promotor sites for in vitro transcription following the NEB manufacturer's protocol. pSP72-CTG90 was cut with BamHI-HF or EcoRI-HF using the following general procedure. To a $1.5 \mathrm{~mL}$ Eppendorf tube was added 435.9 $\mu \mathrm{L}$ of nuclease-free water, $52.5 \mu \mathrm{L}$ of 10X CutSmart Buffer (1X final concentration), and $26.1 \mu \mathrm{L}$ of pSP72-CTG90 ( $1 \mu \mathrm{g}$ of DNA from $400.1 \mathrm{ng} / \mu \mathrm{L}$ stock). The tube was flicked to mix and $49 \mu \mathrm{L}$ of the mixture was distributed into to $10-0.5 \mathrm{~mL}$ Eppendorf tubes. To each of the tubes was added $1 \mu \mathrm{L}$ of restriction enzyme (BamHI-HF or EcoRI-HF, $1 U$ ). The reaction was incubated at $37{ }^{\circ} \mathrm{C}$ for $15 \mathrm{~min}$ in a PCR thermocycler. Shrimp alkaline phosphatase $(2 \mu \mathrm{L})$ was added to each tube and incubated for an additional $30 \mathrm{~min}$ at $37{ }^{\circ} \mathrm{C}$. The cleavage reactions were purified using the QIAquick PCR Purification kit to remove remaining proteins following the kit protocol (two $50 \mu \mathrm{L}$ reactions per spin column). The DNA was eluted with $30 \mu \mathrm{L}$ elution buffer and the concentrations were measured with a Thermo Scientific NanoDrop using the extinction coefficient for DNA.

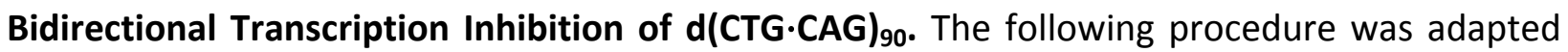
from previously reported procedures. ${ }^{4,5} \mathrm{~A}$ master mix was made by combining rNTPs ( $1 \mu \mathrm{L}$ of each rNTP per reaction, $1 \mathrm{mM}$ final concentration, $10 \mathrm{mM}$ stock from NEB) and RNA Pol Buffer (1 $\mu \mathrm{L}, 1 \mathrm{X}$ final concentration, 10X stock from NEB). To a $0.5 \mathrm{~mL}$ Eppendorf tube was added $1 \mu \mathrm{L}$ of linear plasmid (plasmid was first diluted to $15 \mathrm{ng} / \mu \mathrm{L}, 15 \mathrm{ng}$ added to each reaction) with either the SP6 (EcoRI cleavage) or T7 (BamHI cleavage) promoter ahead of the repeat region and $5 \mu \mathrm{L}$ of the master mix described above. Compounds were diluted to $125 \mu \mathrm{M}, 25 \mu \mathrm{M}$, and $2.5 \mu \mathrm{M}$ from $10 \mathrm{mM}$ stocks and the appropriate amount each compound to reach the desired final concentration was added to each reaction tube. Molecular biology grade water $(4 \mu \mathrm{L})$ was added to mock reaction as a control. The tubes were flicked to mix and incubated at $37{ }^{\circ} \mathrm{C}$ for $3.5 \mathrm{~h}$. Polymerase (T7 or SP6, $1 \mu \mathrm{L}, 50,000 \mathrm{U} / \mathrm{mL}$ or $20,000 \mathrm{U} / \mathrm{mL}$ stock, NEB) was added to each tube. The transcription reaction was incubated at $37{ }^{\circ} \mathrm{C}$ for $1.5 \mathrm{~h}$. To stop the reaction, a quenching solution of $6.5 \mu \mathrm{L}$ of $8 \mathrm{M}$ urea and $1 \mu \mathrm{L}$ of RNA denaturing dye (95\% formamide, $5 \mathrm{mM}$ EDTA, $0.025 \%$ each xylene cyanol and bromophenol) was added to each tube. The RNA was denatured by heating to $95{ }^{\circ} \mathrm{C}$ for $5 \mathrm{~min}$ and cooling to $4{ }^{\circ} \mathrm{C}$. To quantify, RNA was run on a $10 \%$ urea PAGE gel $(8 \mathrm{M})$ at $250 \mathrm{~V}(80 \mathrm{~mA})$ for $25 \mathrm{~min}$. Gels were post-stained at room temperature for $15 \mathrm{~min}$ with ethidium bromide (15 $\mu \mathrm{L}, 10 \mathrm{mg} / \mathrm{mL}$ solution in $\sim 15 \mathrm{~mL}$ DI water), imaged on a BioRad Gel Dock XR, and quantified in Fiji/ImageJ $(\mathrm{NIH})$ based on band intensity. Percent transcription inhibition is defined as 1 - (ligand treated/mock). Data in Figure $4 \mathrm{C}$ was plotted in RStudio and fitted to a logistic curve using the SSlogis model. The output logistic equation was used to calculate $\mathrm{IC}_{50}$ for each ligand, reported in Figure $4 \mathrm{C}$. 


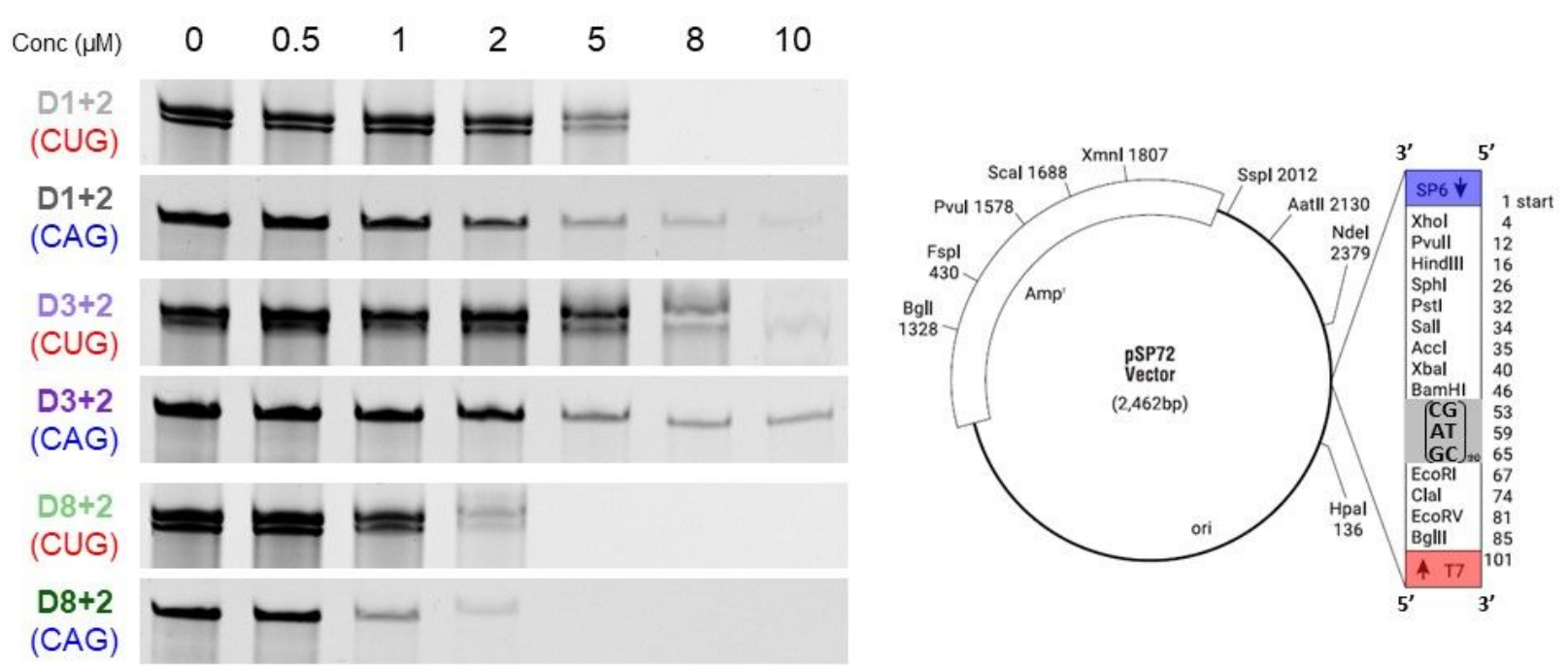

Figure S5. Gel images for bidirectional transcription inhibition of $d(C T G \cdot C A G)_{90}$ by D1+2, D3+2, and $\mathbf{D} \mathbf{8}+\mathbf{2}$ at varying concentrations. Percent transcription inhibition is defined as 1 - (ligand treated/mock). Error is reported as the standard error of the mean for 3 independent replicates.

Bidirectional Transcription Inhibition of control plasmid (pTRI-Xef). Control experiments were performed as above using the control sequence pTRI-Xef (ThermoFischer, MEGAscript KIt) that has consecutive SP6 and T7 transcription sites. Upon transcription with SP6 or T7, a 1.92 of 1.89 $\mathrm{kb}$ transcript is made, respectively. The plasmid was diluted to $15 \mathrm{mg} / \mathrm{mL}$ and the reactions were performed in the same manner as described above. To quantify the amount of RNA, the products were run on a $5 \%$ agarose gel. Gels were pre-stained with EtBr and quantified in the same manner as described above.
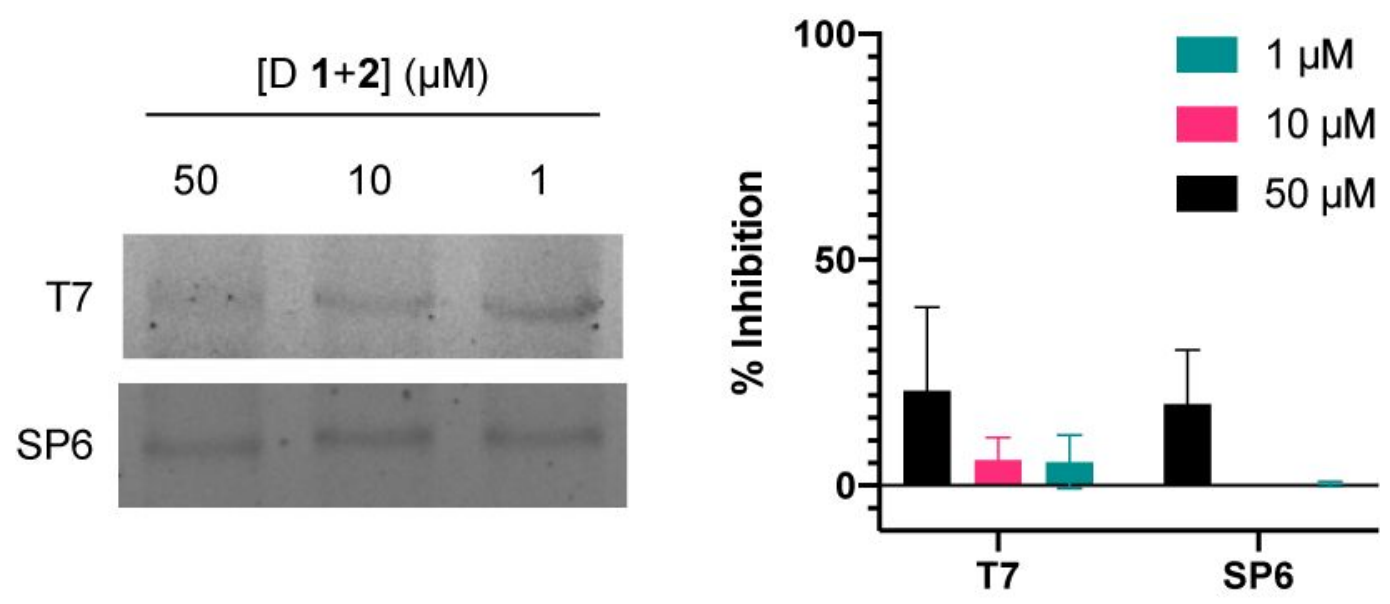

Figure S6. Bidirectional transcription inhibition of pTRI-Xef by D 1+2 at varying concentrations. Percent transcription inhibition is defined as 1 - (ligand treated/mock). Error is reported as the standard error of the mean for 3 independent replicates. 


\section{References}

(1) Hagler, L.D.; Luu, L.M.; Tonelli, M.; Lee, J.; Hayes, S. M.; Bonson, S. E.; Vergara, J. I.; Butcher, S. E.; Zimmerman, S. C. Expanded DNA and RNA Trinucleotide Repeats in Myotonic Dystrophy Type 1 Select Their Own Multitarget, Sequence-Selective Inhibitors. Biochemistry 2020, 59 (37), 3463-3472.

(2) Luu, L. M.; Zimmerman, S. C. Approaches to the Assembly of Potent Therapeutic Agents for the Treatment of Myotonic Dystrophy. Doctoral Dissertation, University of Illinois at Urbana-Champaign, 2016.

(3) Tsitovich, P. B.; Pushechnikov, A.; French, J. M.; Disney, M. D. A Chemoenzymatic Route to Diversify Aminoglycosides Enables a Microarray-Based Method to Probe Acetyltransferase Activity. ChemBioChem 2010, 11 (12), 1656-1660.

(4) Nguyen, L.; Luu, L. M.; Peng, S.; Serrano, J. F.; Chan, H. Y. E.; Zimmerman, S. C. Rationally Designed Small Molecules That Target Both the DNA and RNA Causing Myotonic Dystrophy Type 1. J. Am. Chem. Soc. 2015, 137 (44), 14180-14189.

(5) Lee, J.; Bai, Y.; Chembazhi, U. V.; Peng, S.; Yum, K.; Luu, L. M.; Hagler, L. D.; Serrano, J. F.; Chan, H. Y. E.; Kalsotra, A.; Zimmerman, S. C. Intrinsically Cell-Penetrating Multivalent and Multitargeting Ligands for Myotonic Dystrophy Type 1. Proc. Natl. Acad. Sci. 2019, 116 (18), 8709-8714. 